\title{
Winner versus Loser: Time-Varying Performance And Dynamic Conditional Correlation
}

\author{
Zhongyi Xiao, Texas Tech University, USA \\ Peng Zhao, Chongqing University, China \\ Masha Rahnama, Texas Tech University, USA \\ Yaling Zhou, Southwest University, China
}

\begin{abstract}
Using multi-factor models in OLS and GARCH-M methodology, this paper provides a crosssectional and time-series investigation of conditional and unconditional expected returns of real REITs index momentum portfolios against real estate property, large-cap stock small-cap stock, and bond index in USA. The expected returns and dynamic conditional correlations between REITs and those of other financial and tangible assets vary in period 1989-2010. REITs returns exhibit a higher correlation with up move of financial market, but a lower correlation in market downturns. REITs may possibly provide diversification benefits to multi-asset investment portfolio. We find that the performances of momentum returns are different from the NAREIT index, and display asymmetric volatility as well. Additionally, we find evidence that REITs momentum returns are varying between winner and loser by Wald test. The results of regressions also indicate that REITs return exhibits the greater sensitivity to large- and small-cap stock index, and less closely with those of bond and real estate index. The results also suggest that REITs not be viewed as a complete substitute for investment in tangible property of real estate.
\end{abstract}

Keywords: REITs; Momentum return; Dynamic conditional correlation; GARCH-M model

\section{INTRODUCTION}

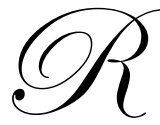

eal estate investment trusts (REITs) is a useful way to channel and structure the capital flow to the real estate market (Glascock et al., 2000). Historical statistics indicate that the market capitalization of the REITs industry amounted to $\$ 389.3$ billion at the end of 2010, representing an increase of 260 times since 1971. REITs have emerged as means for both institutional and small investors to hold, and invest in diverse property assets after 1992. Like any other public-traded stocks, REITs are listed and traded on major stock exchanges, most listed on NYSE. REITs returns have been extensively studied in order to understand the return generating process (Li and Wang., 1995; Payne, 2003, Chui et al., 2003a) and time-series property of REITs during the last two decades (Liu and Mei, 1992; Vinod, 1999; Clayton and MacKinnon, 2001; Chiang and Kung, 2005; Hung and Glascock, 2008; Case et al., 2010; Fei et al., 2010).

With a better understanding about market driven-force for REITs, the REITs returns may work to better reflect its true value, and thereby a stronger correlation to the investor, as well as academics. This benefit critically relies on the correlation properties between REITs returns and market factors. Several studies reveal the fundamental relationship between REIT and real estate market returns (Clayton and Mackinnon, 2003). At the "REITs Boom" age of the 1990s, there is a high correlation between NAREIT index and NCRECF returns (Giliberto, 1990; Ghosh et al., 1996), and the dramatic growth and maturation of REIT sector makes REITs seem more like real estate, and less like stock (Meyer and Webb, 1993; Liang and McIntosh, 1998). Glascock et al. (2000) analyzed the cointegration between the equity REIT and unsecuritized real estate. Barkham and Geltner (1995) show a co-movement between REITs with unsecuritized real estate return, suggesting the return of REITs price changes 
more rapidly than property value. Other studies also argue the segmentation between the unsecuritized real estate and the stock market (Liu et al., 1990; Gilioberto, 1990). Overall, there is still no consensus on the relationship between REITs and unsecuritized real estate (Glascock et al., 2000).

The empirical literature in the link between REITs and stocks is also inconclusive. Sagalyn (1990) finds that risk and return level of REITs may depend on business cycles and the trend of the market return. It has been pointed out that the stock market has a significant impact on the REITs return (Nelling and Gyourko, 1998; Clayton and MacKinnon, 2001; Stevenson, 2002; Chang et al., 2011), and REITs could be best described in terms of portfolios of stock and bond (Sander and Karolyi, 1998). Swanson et al. (2002) finds that REITs are more sensitive to maturity rate spread between treasuries and bonds. Subrahmanyam (2007) considers REITs as a substitute investment for the stock, which causes down-moves in the stock market to increase money flows to the REITs market. Additionally, the inclusion of REITs in the Standard and Poor's major indices led to the return of REITs behaving more like stocks, and particularly increased the influence of sentiment in determining REITs market (Wu and Huang, 2011). On the other hand, Goodman (2003) reveals a low correlation between REITs returns and housing price in a sample spanning from 1976 to 2001, and states that REITs are independent of market changes.

Therefore, the diversification benefit for REITs appears to be very time-dependent. Liang et al.(1995) used a two index (large-cap stock index and bond index) model of return generating process for REIT and found a structure break in return of equity REIT. Neilingand and Gyourko (1998) applied a multi-factor for REIT and found that the risk of equity REITs is higher in bear stock market than in bull markets. Chui et al.(2003a) find that return volatility and earning volatility for REIT were much greater in the 1990s than in 1980s. Fei (2010) points out REITs exhibit the character of high return when correlation between REIT and S\&P500 is the lowest. However, the limitation of the previous model is that they ignore the influence of market interactions between multiple market indices with REITs (Glascock et al., 2002).

This research was inspired by a large number of studies that explored pattern in REITs returns, and by studies that built on those patterns to develop factor model that could evaluate the dynamic changes of return in REITs. They examine the cross-sectional sensitivity of REITs to broad asset classes including market portfolio return, large-cap stocks, small-cap stocks, bonds and real estate over the years 1989-2010, which cover both bloom and recession periods. The time-series study is taken to see if there is a pattern in volatility of REITs index and in correlation with other asset classes. In addition, this article explores the time-series behavior of REITs return to see if there are simple laws for expectation of the REITs return, and it also evaluates whether the time-varying factors could jointly explain the momentum returns of REITs. Another difference from previous literature of this study is that it extends to the range of analysis to December, 2010 with the monthly data. This paper eliminates the limitation of the quarterly property index by implication of S\&P/Case-Shiller Home price monthly index, as a proxy for the unsecuritized real estate market to extend the observation. Because REITs are traded in the general exchange market and particularly composited in major stock indices, they might result in overstating the correlation between REITs and non-REITs stocks (Case et al., 2010). Therefore, the CRSP Cap-Based Portfolio Index that excludes REITs is introduced as a second proxy for the stock market. Jegadeesh and Titman (1993) first report the moment effect of stock portfolios by examining U.S stock market. Though similar researches are also then applied into REITs market analysis (Ling and Ryngaert, 1997; Chui et al., 2003b; Joseph et al., 2009; Hung and Glascock, 2010), recent outcomes still cannot reach a conclusive explanation of on momentum strategy.

The dynamic conditional correlations of REITs portfolios with market index are examined by Engle DCC estimator (Engle, 2002). The DCC results evidence the time-varying feature of REITs portfolio reflecting the market information, and show the different strategy of winner and loser investment. The study follows the classic Capital Asset Pricing Model (CAPM) and the multi-factor model developed from four-factor model (Clayton and MacKinnon, 2001) as the frame to investigate the link of REITs with other asset classes. The results of regressions indicate that REITs return exhibit the greatest sensitivity to market return, followed by large- and small-cap stock index, bond index and real estate index. Wald test evidenced the winner and loser portfolios display varying sensitivities to the market information. Our regressions supports the momentum effect in REITs returns outperform winner REITs portfolio over loser REITs portfolio. Given the strength of the momentum effect in the sample period, 
this paper also examines the time-varying changes in REITs return via general autoregressive conditional heteroskedasticity based model (GARCH-M). In fact, we find the momentum effects for returns REITs index, winner and loser are time-varying.

The rest of the paper is organized as follows. In the next section, we show data, construction of portfolio. In the Section III, we state the empirical framework and a series of regression models. In the Section IV, the unconditional and conditional analysis of REITs is discussed. Section IV reports the empirical analysis of the regression models in cross-section and time-series to characterize the sensitivity and profitability. The last section concludes this study.

\section{DATA}

To estimate the dynamic nature of REITs, this article uses monthly returns of REITs index and market indices from January, 1989 to December, 2010. Monthly REITs performance is proxy by FTSE NAREIT ALLREIT index, including all three types REITs (equity, mortgage and hybrid) listed on NYSE, AMEX and NASDAQ. The Russell2000 index $(R U S L)$ and S\&P500 index $(S \& P)$ are as the proxy for the small- and large-cap stock market, respectively. Barclay Capital long-term Government/Corporate bond index $(B C L B)$ is the proxy for bond market return. Because REITs are now included in general stock market indexes, the correlation between a REITs index and a general stock market index overstates the correlation between REITs and non-REITs stocks; therefore, we also use the CRSP Cap-Based Portfolio Index $(C A P)$ as an alternative stock index proxy, which excludes REITs to avoid the potential data bias resulting from the inclusion of REITs (Case et al., 2010). Following the majority studies, we define the FAMA-FRENCE variable of market portfolio return $R_{m}$ as the monthly returns on a portfolio composed of all NYSE-AMEX-NASDAQ stocks. The S\&P/Case-Shiller home price index $(C S P)$ is the leading measure of the property index for U.S. real estate market. The one-month Treasury bill rate from Ibbotson is used as a proxy for the risk-free rate $\left(R_{f}\right)$.

The data of publically-traded REITs traded on NYSE, AMEX and NASDAQ during the period from January, 1988 to December 2010 is collected CRSP database. Under assumption of free allocating the REITs portfolio, this study does not examine the transaction costs incurred for trading these assets. The procedure of forming portfolios was followed the method described by Jegadeesh and Titiman (1993). To form the momentum portfolios, at the end of each month, we rank all REITs in our sample in ascending order based on the past 11 month cumulative return with dividend, and all sample REITs is required to survive at least 18 months. Hereby, the 15 REITs with the lowest (highest) returns are referred to as the loser (winner) portfolio.

\section{METHODOLOGY}

\subsection{Dynamic conditional correlations}

Correlations are critical approach for many of the common tasks of financial managements. As the change of correlation and volatility, the efficient allocation of assets should rapidly be adjusted to reflect new public information. The approach of conditional correlation is based on information known in the previous period in allowing the correlation matrix to be time varying. Constant Conditional Correlation (CCC) is one type of benchmark estimator (Bollerslev, 1990), and it is extended to the Dynamic Conditional Correlation (DCC) estimator by implication of GARCH model (Engle, 2002). The model imposes a useful structure on the many possible model parameters. This article uses the DCC estimator as shown in Equation (1). Engle (2002) simply states the correlation estimator by a geometrically weighted average of standardized residuals, which can be expressed as Equation (2).

$H_{t}=D_{t} R_{t} D_{t}$

$\rho_{i, j, t}=\frac{\sum_{s=1}^{t-1} \lambda^{s} \varepsilon_{i, t-s} \varepsilon_{j, t-s}}{\sqrt{\sum_{s=1}^{t-1} \lambda^{s} \varepsilon_{i, t-s}^{2}} \sqrt{\sum_{s=1}^{t-1} \lambda^{s} \varepsilon_{j, t-s}^{2}}}$ 
Where $H_{t}$ is a $\mathrm{k} \times \mathrm{k}$ conditional covariance matrix; $R_{t}$ is a $\mathrm{k} \times \mathrm{k}$ conditional correlation matrix; $D_{t}$ is a $\mathrm{k} \times \mathrm{k}$ diagonal matrix of time-varying standard deviations of residual returns, $D_{t}=\operatorname{diag}\left\{\sqrt{D_{t}}\right\}$.

\subsection{Cross-sectional Analysis of REITs performance}

Actively managed portfolio is typically evaluated by the return that generated in excess of expected return on a passive benchmark return as:

$\alpha_{i, t}=R_{i, t}-R_{f, t}$

Where $R_{i, t}$ denotes either the average return of $i$ REITs index or portfolios at time $t$, and $R_{f, t}$ denotes the return of one-month Treasury bill. A positive $\alpha_{i, t}$ indicates the successful investment, and the negative $\alpha_{i, t}$ indicates the failure of investment.

Three reduced-form models are applied for the analysis. The first model (Equation 3) is a single-factor model in the tradition of Capital Asset Pricing Model (CAPM), in which the expected return is a function of systematic risk. The estimated version of the CAPM predicts the relationship between beta and excess return. The second model (Equation 4) is similar to the four-factor model developed from Clayton and Mackinnon (2001), including the indices of both financial assets and the unsecuritized real estate asset. In this model, the excess return of $R_{R E I T S, t}$ is described by the following return generating process. The third model (Equation 5) adds the excess return of Fama-French portfolio to the four-factor model to examine the behavior of REITs with respect to the broad market signals.

$\left(R_{R E I T S, t}-R_{f, t}\right)=\beta_{0}+\beta_{m}\left(R_{m, t}-R_{f, t}\right)+\varepsilon_{t}$

$\left(R_{R E I T S, t}-R_{f, t}\right)=\beta_{0}+\beta_{S \& P} R_{S \& P, t}+\beta_{R U S L} R_{R U S L, t}+\beta_{C A P} R_{C A P, t}+\beta_{C S P} R_{C S P, t}+\beta_{B C L B} R_{B C L B, t}+\varepsilon_{t}$

$\left(R_{R E I T S, t}-R_{f, t}\right)=\beta_{0}+\beta_{m}\left(R_{m, t}-R_{f, t}\right)+\beta_{S \& P} R_{S \& P, t}+\beta_{R U S L} R_{R U S L, t}+\beta_{C A P} R_{C A P, t}+\beta_{C S P} R_{C S P, t}+\beta_{B C L B} R_{B C L B, t}+\varepsilon_{t}$

Where $R_{S \& P, t}$ is the monthly return to the S\&P500 large-cap stock index, $R_{R U S L, t}$ is the monthly return to the Russell2000 small-cap index, $R_{C A P, t}$ is the return to the CRSP Cap-based portfolio index, $R_{C S P, t}$ is $\mathrm{S} \& \mathrm{P} /$ Case-Shiller home price index proxy for monthly unsecuritized real estate index, and $R_{B C L B, t}$ is the return to the Barclay Capital long-term Government/Corporatebond index.

\subsection{Time-series analysis of REITs performance}

The CAPM model provides the theoretical foundation for the trade-off relationship between risk and excess return. Indeed, risk is to be measured by the conditional covariance of returns with the market. However, risks may vary over time in practice. Previous researches find that the returns of real estate asset exhibit negative skewness and excess kurtosis (Bond and Patel, 2002). Engle (1992) creates the ARCH model, and generalized to GARCH model by Bollerslev (1986). The framework was further extended to ARCH- and GARCH-in-mean (ARCH-M and GARCH-M) by Engle et al. (1987), and allows for a analysis of time-varying risk premium. Therefore, an application of GARCH-M estimation to capital asset pricing model may improve the performance of estimation by permitting risk to be time-variant. More specifically, negative shocks typically increase volatility greater than positive shocks of equal magnitude (Henry, 2008). In other words, negative returns cause an upward revision of the conditional volatility, whereas positive returns cause a smaller upward or even a downward revision of the conditional volatility. In this research, we extend the CAPM model and multiple factors model with a GARCH-M model to study asymmetric volatility of momentum returns in REITs. Therefore, the fourth model is used for estimating CAPM with a GARCH-M model is as Equation (4). Volatility of portfolio returns is measured by conditional variance $h_{t}$, which is defined as a function of squared values of the past residuals, presenting the ARCH factor, and an auto regressive term $\left(h_{t-1}\right)$ presenting the GARCH factor. The parameters, such as $\beta_{i} s, \gamma_{h}, \alpha_{i} s$, are estimated via regression. Next, we apply GARCH-M model to the model 5 as Equation (7). The last model (Model 
6) is GARCH-M model to CAPM with Multiple factors model in model 6 as Equation (8).

$$
\begin{aligned}
& \left(R_{i, t}-R_{f, t}\right)=\beta_{0}+\beta_{m}\left(R_{m, t}-R_{f, t}\right)+\gamma_{h} \sqrt{h}_{t}+\varepsilon_{t} \\
& \left(R_{i, t}-R_{f, t}\right)=\beta_{0}+\beta_{S \& P} R_{S \& P, t}+\beta_{R U S L} R_{R U S L, t}+\beta_{C A P} R_{C A P, t}+\beta_{C S P} R_{C S P, t}+\beta_{B C L B} R_{B C L B, t}+\gamma_{h} \sqrt{h}+\varepsilon_{t} \\
& \left(R_{i, t}-R_{f, t}\right)=\beta_{0}+\beta_{m}\left(R_{m, t}-R_{f, t}\right)+\beta_{S \& P} R_{S \& P, t}+\beta_{R U S L} R_{R U S L, t}+\beta_{C A P} R_{C A P, t}+\beta_{C S P} R_{C S P, t}+\beta_{B C L B} R_{B C L B, t}+ \\
& \gamma_{h} \sqrt{h} t \\
& h_{t}=\alpha_{0}+\alpha_{1} \varepsilon_{t-1}^{2}+\alpha_{2} h_{t-1} \\
& \varepsilon_{t} \mid \Omega_{t} \sim \text { iid. } N\left(0, h_{t}\right)
\end{aligned}
$$

These models described above are to test whether $\gamma_{h}$ equals to zero. If $\gamma_{h}$ equals to zero, there is no relationship between volatility and return. The $\gamma_{h}$ is interpreted as the coefficient of relative risk aversion of investors. These authors point out that $\gamma_{h}$ is a time-varying risk premium, and the sign and magnitude of $\gamma_{h}$ depend on utility functions of investors. As a result, $\gamma_{h}$ can be positive, negative or zero. A positive $\gamma_{h}$ indicates a higher risk premium required by investors when volatility is high, while a negative $\gamma_{h}$ means a lower risk premium required by investors when volatility is high. However, there are no consensus about the signs of $\gamma_{h}$ because of the different relation between volatility and expected return (Campbell and Hentschel, 1992; Nelson, 1990; and Glosten et al., 1993). Three null hypotheses are tested in this paper. First, NAREIT index return and portfolio return display an asymmetric volatility. In other words, the higher the volatility, the higher the momentum returns. Second, winner and loser portfolios exhibit different magnitudes of risk premium (measured by the $\gamma_{h}$ coefficient) corresponding to volatility (measured by $h_{t}$ ). If rational risk-return theory is held, we should find positive $\gamma_{h}$ for both winner and loser, and the winner should have a higher $\gamma_{h}$ than losers. On the other hand, it contradicts risk-return tradeoff theory, if $\gamma_{h}$ is negative. Third, winner and loser portfolios display different sensitivity and strategy to the broad market signals. We, therefore, apply these cross-sectional and time-series models to returns of NAREIT index, winner and loser portfolios.

\section{DESCRIPTIVE DATA ANALYSIS}

\subsection{Unconditional means and correlations of REITs and market indices}

Table 1 gives the summary of the means and standard deviations of monthly excess return on the NAREIT index, Russell2000 index, S\&P500 index, Barclay capital long-term Government/Corporate bond index, CRSP capbased portfolio index, and S\&P/Case-Shiller home price index over the period 1989-2010. It shows that the NAREIT index outperformed the other indices based on average return over the entire sample period in the two past decades. The REITs displays the characteristic of negative skewness as reported by Bond and Patel (2002). Additionally, the return of REITs holds the high volatility as well as Russell2000 index over the entire period, but the REITs index had a lower monthly standard deviation of these assets over the entire sample period as well as most sub-periods. The historical performance of the NAREIT index based on Sharpe ratio does not hold the highest position as research of Vinod (1999). Furthermore, the statistics also suggest the winner portfolio has a monthly average excess return of 1.63 with a higher Sharpe ratio 0.23 , whereas the loser portfolio has a monthly excess return of 0.27 with the lowest Sharpe ratio equal to 0.03 . Interestingly, neither winner portfolio nor loser portfolio display the negative skewness. The result suggests that momentum return might generate mostly from a long position in winner portfolio. 
Table 1: Descriptive statistics of monthly excess returns

\begin{tabular}{lccccccccc}
\hline Statistics & NAREIT & Winner & Loser & RM & S\&P & RUSL & CAP & CSP & BCLB \\
\hline Mean & 0.43 & 1.63 & 0.27 & 0.56 & 0.11 & 0.48 & 0.56 & -0.05 & 0.28 \\
Min & -30.31 & -23.55 & -43.26 & -18.54 & -4.76 & -20.98 & -17.07 & -2.31 & -3.43 \\
Max & 27.96 & 56.38 & 47.12 & 11.04 & 4.79 & 15.99 & 10.81 & 1.80 & 3.64 \\
Std.Dev & 5.30 & 7.01 & 10.10 & 4.49 & 0.90 & 5.61 & 4.45 & 0.84 & 1.11 \\
Kurtosis & 8.21 & 14.21 & 4.92 & 1.37 & 5.85 & 1.01 & 1.09 & -0.03 & 0.44 \\
Skewness & -0.84 & 1.59 & 0.15 & -0.74 & 0.21 & -0.57 & -0.68 & -0.31 & -0.25 \\
S.R. & 0.08 & 0.23 & 0.03 & 0.12 & 0.12 & 0.09 & 0.13 & -0.06 & 0.25 \\
Beta & 0.196 & 1.058 & 0.304 & 1.00 & -0.05 & 1.10 & 0.99 & 0.01 & 0.03 \\
\hline
\end{tabular}

Note: All mean excess return and standard deviation of excess returns are in percentage per month.

Prior to estimation, it is important to check the potential for multicollinearity among the returns of REITs, stock, bond and real estate. Table 2 displays the realized correlations of monthly excess return on the NAREIT index with the excess returns on the other financial assets and real estate assets over the entire sample period. NAREIT index shows the highest correlation with Russell2000 at 0.65 . Interestingly, the NAREIT index has negative correlations with S\&P500 as low as -0.25 , and has a relative low correlation with the S\&P/Case-Shiller home price index. The value of property is driven by the general economic conditions and correlated to the positive expected return and solid long-term performance. The lower correlations of REITs to the broader market, the alternative investment tool as REITs offered an increase hedge benefit to both institutional and small investors.

Table 2: Unconditional Correlations of monthly excess returns

\begin{tabular}{|c|c|c|c|c|c|c|c|c|}
\hline & NAREIT & Winner & Loser & $\mathbf{R M}$ & S\&P & RUSL & CAP & CSP \\
\hline $\mathrm{RM}$ & 0.58 & 0.56 & 0.57 & & & & & \\
\hline $\mathrm{S} \& \mathrm{P}$ & -0.25 & -0.41 & -0.26 & -0.24 & & & & \\
\hline RUSL & 0.65 & 0.69 & 0.62 & 0.88 & -0.54 & & & \\
\hline CAP & 0.56 & 0.56 & 0.56 & 1.00 & -0.22 & 0.88 & & \\
\hline CSP & 0.15 & 0.09 & 0.03 & 0.06 & -0.05 & 0.07 & 0.06 & \\
\hline BCLB & 0.18 & 0.01 & 0.06 & 0.13 & 0.07 & 0.04 & 0.13 & -0.02 \\
\hline
\end{tabular}

\subsection{Conditional means and correlations in REITs}

Let $r_{t}$ denote the return on the NAREIT index in month $t$ and $r_{t-1}$ denote the return on the index in month $t-1$. Each month $t$ is classified by whether the return in the previous month, $r_{t-1}$, was positive or negative. This gives rise to two sets of returns. The first set consists of the returns on the index in months following a positive return on other the indices, and the second set consists of returns on the index in months following a negative return on other indices. The summary statistics of these two sets of returns for the NAREIT index and financial assets are presented in Table 3. The standard deviation of the return on the NAREIT following down is higher than that following up months. The same pattern is also seen for the Russell2000 index, Barclay Capital long-term Government/Corporate bond index, and CRSP Cap-based portfolio index. In addition to variance, the covariance matrix is applied to test whether the correlation matrix from months following up move in the NAREIT is similar to the correlation matrix from months following down move. Table 3 presents that there is no constant correlation over the period under the vary condition. For example, the correlation of NAREIT with the S\&P500 in following down move months are lower than that the correlations following up move months in overall period as well as in the sub-periods. In addition, the NAREIT shows positive correlations with Russell2000, CRSP Cap-based portfolio and Case-Shiller Home Price index, and a negative correlation with S\&P500 in these indices following up and down moves, respectively. These results in mean returns, variances, and covariance in the NAREIT with other financial and tangible assets show the evidence of the momentum effect and time-varying of correlations for the implication of a 
predictable manner. While a statistically significant link between REITs and small-cap stock returns is observed, there is a cyclical component to this relationship, as REITs returns appear to be much more sensitive to small-cap stock returns when the REITs market is in a downturn, and less sensitive in REITs bull markets.

Table 3: Mean, Stand. Dev. and conditional of correlations of REITs returns following up moves and down moves in Indices

\begin{tabular}{|c|c|c|c|c|c|c|}
\hline Index & Return Type & Statistic & Number of Months & NAREIT & Winner & Loser \\
\hline \multirow[t]{4}{*}{$\mathrm{S} \& \mathrm{P}$} & Following Up Move & $\mu(\sigma)$ & 165 & $1.38(4.56)$ & $2.54(7.11)$ & $3.10(11.09)$ \\
\hline & & $\hat{\rho}$ & & 0.21 & 0.24 & 0.29 \\
\hline & Following Down Move & $\mu(\sigma)$ & 99 & $0.09(6.24)$ & $0.75(6.74)$ & $-1.22(10.67)$ \\
\hline & & $\hat{\rho}$ & & 0.28 & 0.10 & 0.26 \\
\hline \multirow[t]{4}{*}{ RUSL } & Following Up Move & $\mu(\sigma)$ & 166 & $1.28(4.73)$ & $2.72(7.25)$ & $3.29(11.13)$ \\
\hline & & $\hat{\rho}$ & & 0.18 & 0.11 & 0.26 \\
\hline & Following Down Move & $\mu(\sigma)$ & 98 & $0.20(6.08)$ & $0.44(6.40)$ & $-1.55(10.49)$ \\
\hline & & $\hat{\rho}$ & & 0.15 & 0.07 & 0.16 \\
\hline \multirow[t]{4}{*}{$\mathrm{CAP}$} & Following Up Move & $\mu(\sigma)$ & 168 & $1.47(4.57)$ & $2.72(7.07)$ & 3.37 (10.99) \\
\hline & & $\hat{\rho}$ & & 0.18 & 0.23 & 0.28 \\
\hline & Following Down Move & $\mu(\sigma)$ & 96 & $-0.1(6.24)$ & $0.37(6.70)$ & $-1.83(10.61)$ \\
\hline & & $\hat{\rho}$ & & 0.23 & 0.05 & 0.23 \\
\hline \multirow[t]{4}{*}{ CSP } & Following Up Move & $\mu(\sigma)$ & 185 & $1.09(3.97)$ & $2.25(7.16)$ & $1.40(9.16)$ \\
\hline & & $\hat{\rho}$ & & 0.05 & -0.12 & -0.04 \\
\hline & Following Down Move & $\mu(\sigma)$ & 79 & $0.45(7.52)$ & $0.98(6.62)$ & $1.65(14.78)$ \\
\hline & & $\hat{\rho}$ & & 0.28 & 0.29 & 0.10 \\
\hline \multirow[t]{4}{*}{ BCLB } & Following Up Move & $\mu(\sigma)$ & 187 & $1.47(4.81)$ & $2.05(7.23)$ & $2.02(11.13)$ \\
\hline & & $\hat{\rho}$ & & 0.06 & 0.15 & 0.12 \\
\hline & Following Down Move & $\mu(\sigma)$ & 77 & $-0.50(6.13)$ & $1.45(6.53)$ & $0.08(11.09)$ \\
\hline & & $\hat{\rho}$ & & 0.25 & 0.12 & 0.22 \\
\hline
\end{tabular}

Note: $\mu$ denotes the mean; $\sigma$ in the parenthesis denotes standard deviation; $\hat{\rho}$ denotes the conditional correlation of REITs following up or down move in indices.

\subsection{Estimator of Dynamic conditional correlation in REITs portfolio}

In term of considering further details of conditional correlation, we estimate the dynamic conditional correlations REITs portfolios with broad market indices relying on approach of previous studies. To visualize the computed DCC, we have graphed them in Figure 1. Figure 1 provides individual DCC plots for pair-wise of market indices with either winner or loser portfolios over the period 1989-2010. In visual result, the winner and loser portfolios exhibit different volatility and dynamic character. To check the possible differences, we employ F-test for DCC results for all sections. As a represented by the significance of $p$-value, the tests demonstrate the winner and loser portfolios display different strategies in response to change of the market signals. 

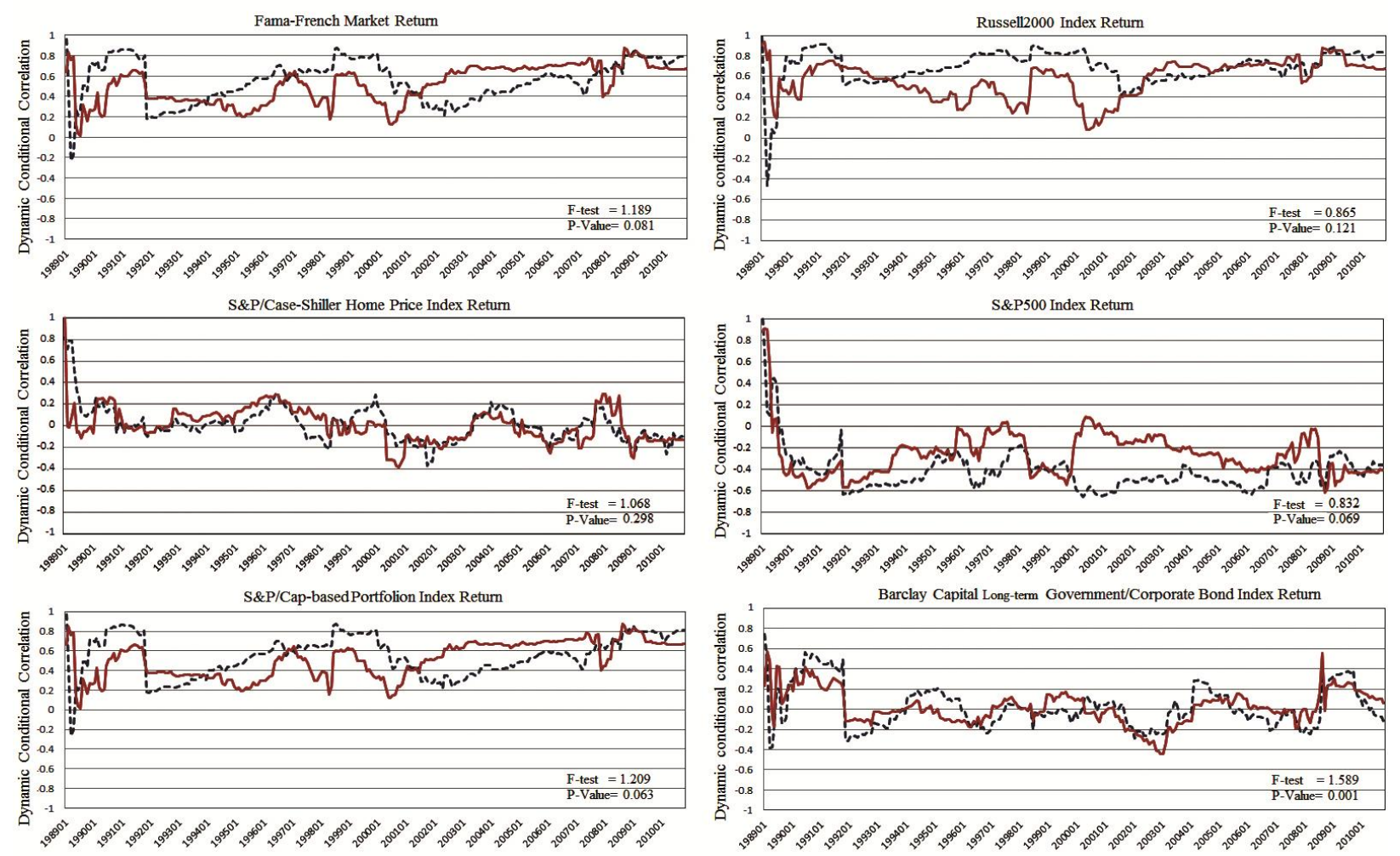

Figure 1: Dynamic Conditional Correlation of Winner and Loser Portfolios

Figure 1 displays the dynamic conditional correlations between the monthly excess returns on the winner portfolio (Blue dash line) and loser portfolio (Red solid line) portfolios with the market index returns, including the index returns of Fama-French market return, Russell200 index, S\&P/Case-Shiller home price index, S\&P500 index, Cap-based Portfolio index, Barclay Capital long-term Government/Corporatebond index, for the sample in period 1989-2010.

\section{EMPIRICALLY REGRESSION OF REITS PERFORMANCE}

\subsection{Cross-sectional analysis}

In this section, we are interested in exam the sensitivities of REITs to returns on four broad asset classes, such as large-cap stock, small-cap stock, bond and real estate over 1989-2010 period by three reduced form models. First, the coefficients for the interception are all positive for each period. Model 1 shows the cross sectional results in NAREIT and REITs portfolios (Table 4). As a result, it shows that both NAREIT and portfolios have a positive and significant response to the excess return of FAMA-FRENCH market return. For the winner portfolio holds the higher the coefficient for the intercept 1.058 ( $p$-value $=0.004)$, and excess return is $0.878(p$-value $=0.000)$. The values of LM test for model 1 indicates the existence of feature of heteroskedasticity. In addition, Wald test shows the difference of sensitive of NAREIT index and REITs portfolios respect to the market excess return. Model 2 shows returns of NAREIT index and REITs portfolios in response to the financial index return and physical real estate index. All REITs are strongly sensitive to the S\&P500 index, Russell2000 index, and CRSP cap-based portfolio index return. Additional Wald test indicates winner portfolio, and loser portfolio are not share the same pattern to the change of the S\&P500 index, Russell2000 index, and CRSP cap-based portfolio index return. Further multi-factor regression is taken by model 3, which adding of excess market return to model 2 , enhances the explanatory of mode by $\mathrm{R}^{2}$. The same as last two models, the effect heteroskedasticity still exists. It is consistent 
with Khoo et al. (1993) and Clayton and Mackinnon (2001), who find that equity REITs beta undergoes a structural change in historical data, with decreasing of REITs beta (with respect to the overall equity market). In sum, the results of cross sectional models show that the REITs portfolios might have different patterns in response to the financial market index and real estate index. On the other hand, the conditional heteroskedasticity of OLS model need to be adjusted by the proper estimation of volatility.

Table 4: Linear Regression of REIT returns in cross sectional analysis

\begin{tabular}{|c|c|c|c|c|c|c|c|c|c|}
\hline & \multicolumn{3}{|c|}{ Model 1} & \multicolumn{3}{|c|}{ Model 2} & \multicolumn{3}{|c|}{ Model 3} \\
\hline & (1) & (2) & (3) & (1) & (2) & (3) & (1) & (2) & (3) \\
\hline \multirow[t]{2}{*}{ Intercept } & 0.196 & $1.058^{* * * *}$ & 0.364 & 0.421 & $1.115^{\mathrm{a}}$ & $1.519^{* *}$ & $1.654^{* * *}$ & $1.385^{* * * *}$ & $3.868^{* * * *}$ \\
\hline & $(0.466)$ & $(0.004)$ & $(0.523)$ & $(0.131)$ & $(0.006)$ & $(0.024)$ & $(0.000)$ & $(0.007)$ & $(0.000)$ \\
\hline \multirow[t]{2}{*}{ RMRF } & $0.680^{* * * *}$ & $0.878^{* * * *}$ & $1.419^{* * * *}$ & & & & $3.846^{* * *}$ & 0.842 & $7.326^{* * * *}$ \\
\hline & $(0.000)$ & $(0.000)$ & $(0.000)$ & & & & $(0.000)$ & $(0.394)$ & $(0.000)$ \\
\hline \multirow[t]{2}{*}{ S\&P } & & & & $3.730^{* * * *}$ & 0.857 & $5.449^{* * * *}$ & $3.786^{* * *}$ & 0.869 & $5.555^{* * *}$ \\
\hline & & & & $(0.000)$ & $(0.189)$ & $(0.000)$ & $(0.000)$ & $(0.183)$ & $(0.000)$ \\
\hline \multirow[t]{2}{*}{ RUSL } & & & & $1.491^{* * * *}$ & $1.294^{* * * *}$ & $2.297^{* * * *}$ & $1.377^{* * * *}$ & $1.269^{* * * *}$ & $2.079^{* * * *}$ \\
\hline & & & & $(0.000)$ & $(0.000)$ & $(0.000)$ & $(0.000)$ & $(0.000)$ & $(0.000)$ \\
\hline \multirow[t]{2}{*}{ CAP } & & & & $-4.603^{* * *}$ & -1.383 & $-6.385^{* * *}$ & $-8.394^{* * * *}$ & -2.212 & $-13.605^{* * * *}$ \\
\hline & & & & $(0.000)$ & $(0.081)$ & $(0.000)$ & $(0.000)$ & $(0.079)$ & $(0.000)$ \\
\hline \multirow[t]{2}{*}{ CSP } & & & & 0.350 & 0.158 & -1.020 & 0.245 & 0.135 & $-1.220^{*}$ \\
\hline & & & & $(0.193)$ & $(0.683)$ & $(0.113)$ & $(0.333)$ & $(0.728)$ & $(0.050)$ \\
\hline \multirow[t]{2}{*}{ BCLB } & & & & $0.693^{* * *}$ & 0.006 & 0.057 & $0.710^{* * * *}$ & 0.010 & 0.091 \\
\hline & & & & $(0.001)$ & $(0.982)$ & $(0.904)$ & $(0.000)$ & $(0.971)$ & $(0.843)$ \\
\hline R-square & 0.33 & 0.31 & 0.33 & 0.57 & 0.49 & 0.44 & 0.62 & 0.49 & 0.48 \\
\hline AIC & 1525.5 & 1682.23 & 1920.69 & 1418.31 & 1610.68 & 1879.78 & 1385.84 & 1611.93 & 1860.54 \\
\hline LM & 17.098 & 10.601 & 24.058 & 26.141 & 191.219 & 56.212 & 36.224 & 194.755 & 71.632 \\
\hline
\end{tabular}

Note: The dependent variables are the excess return of NAREIT index in column (1), winner portfolio in column (2), and loser column in column (3). $* * *, * *$ and $*$ indicate the significant at $99.9 \%$ confidence level, significant at $99 \%$ confidence level, significant at $95 \%$ confidence level, respectively.

\subsection{Time-Series Analysis of REIT performance}

The modeling of financial time-series has been enriched by the class of $\mathrm{ARCH}$ processes, which were introduced by Engle et al. (1987). But with more processes to choose from, like stochastic volatility models or heavy tail distributions, model choice has become a more complicated problem. Some of the more popular variants of models of changing volatility have proved to be various forms of GARCH models. In these models, the volatility process is time varying, and is modeled to be dependent upon both the past volatility and past innovations. These models have been widely used in many applications of stock return data, interest rate data, foreign exchange data and so forth. Taken the advantage of GARCH model for volatility estimation, we introduced GARCH-M model with maximum likelihood for multivariate time-series in this paper.

Empirical results of the momentum effect of REITs performance are test based on the models 4-6 by means of GARCH-M in Equations (4) to (10). The results of GARCH-M estimation show in the Table 5. One first interesting finding is that the $\alpha_{0}$ in all three models are positive for NAREIT index, winner and loser, respectively. Though the $\alpha_{0}$ in for NAREIT index is insignificant in models, the $\alpha_{0}$ of winner and loser portfolios are statistically significant, and obviously greater than the NAREIT index.. In the model 5, the $\alpha_{0}$ of winner portfolio is 13.36 and the $\alpha_{0}$ of loser portfolio is 26.51. In addition, the $\alpha_{0}$ of winner portfolio is 13.91 and the $\alpha_{0}$ of loser portfolio is 24.32 in the model 6. The second finding of my research is that the return of NAREIT index shows that the $\alpha_{1}$ is lower than the $\alpha_{2}$, but the winner portfolio and loser portfolio have higher $\alpha_{1}$. Note that the magnitude of the $\alpha_{1}$, which 
shows the effect of the last period's shock, is greater than that of $\alpha_{2}$, the effect of previous shocks. The results imply both winner and loser are more sensitive to new short-term shock than the long-term ones. This finding is consistent with momentum trading strategy, of which investment decision is more likely to depend on short-term past returns, rather than long-term past returns to forecast future returns. Next, we estimate the $\gamma_{h}$ coefficient for the winner and loser portfolios, respectively. We find the $\gamma_{h}$ has a positive sign for the winner portfolio, but in negative sign for loser portfolio. In models 5 and 6 , the $\gamma_{h}$ of loser are -0.10 and -0.18 , respectively. A negative $\gamma_{h}$ of losers suggests that higher conditional volatility reduces return risk premium required by investors. Glosten et al. (1993) provided two explanations why the relation between volatility and expected return is negative. First, time periods which are relatively more risky could coincide with time periods when investors are better able to bear particular type of risk. Second, a larger risk premium may not be required because investors may want to save relatively more during periods when the future is more risky.

Table 5: Test asymmetric volatility in time series analysis

\begin{tabular}{|c|c|c|c|c|c|c|c|c|c|}
\hline & \multicolumn{3}{|c|}{ Model 4} & \multicolumn{3}{|c|}{ Model 5} & \multicolumn{3}{|c|}{ Model 6} \\
\hline & (1) & (2) & (3) & (1) & (2) & (3) & (1) & (2) & (3) \\
\hline \multirow[t]{2}{*}{ Intercept } & -0.483 & $1.365^{\text {*** }}$ & $1.693^{* *}$ & -0.369 & 0.791 & 1.331 & $3.265^{* *}$ & 0.773 & $2.955^{\text {**** }}$ \\
\hline & $(0.653)$ & $(0.000)$ & $(0.008)$ & $(0.723)$ & $(0.456)$ & $(0.287)$ & (0.006) & (0.504) & $(0.007)$ \\
\hline \multirow[t]{2}{*}{ RMRF } & $0.576^{* * * *}$ & $0.876^{\text {***** }}$ & $1.206^{* * * *}$ & & & & $3.879^{* * * *}$ & 0.937 & $3.633^{* * * *}$ \\
\hline & $(0.000)$ & $(0.000)$ & $(0.000)$ & & & & $(0.000)$ & (0.294) & $(0.000)$ \\
\hline \multirow[t]{2}{*}{$\mathrm{S} \& \mathrm{P}$} & & & & $2.801^{* * *}$ & $1.700^{* * *}$ & $3.744^{* * *}$ & $2.941^{* * *}$ & $1.388^{*}$ & $3.536^{* * * *}$ \\
\hline & & & & $(0.000)$ & $(0.004)$ & $(0.000)$ & $(0.000)$ & $(0.015)$ & $(0.000)$ \\
\hline \multirow[t]{2}{*}{ RUSL } & & & & $1.243^{* * *}$ & $1.444^{* * *}$ & $1.411^{* * *}$ & $1.115^{* * *}$ & $1.346^{* * *}$ & $1.208^{* * *}$ \\
\hline & & & & $(0.000)$ & $(0.000)$ & $(0.000)$ & $(0.000)$ & $(0.000)$ & $(0.000)$ \\
\hline \multirow[t]{2}{*}{ CAP } & & & & $-3.568^{* * * *}$ & $-2.554^{* * *}$ & $-3.950^{* * * *}$ & $-7.426^{* * * *}$ & $-3.075^{* * *}$ & $-7.158^{* * * *}$ \\
\hline & & & & $(0.000)$ & $(0.000)$ & $(0.000)$ & $(0.000)$ & $(0.002)$ & $(0.000)$ \\
\hline \multirow[t]{2}{*}{ CSP } & & & & 0.206 & $0.735^{\text {**** }}$ & 0.019 & -0.163 & $0.705^{* *}$ & -0.191 \\
\hline & & & & $(0.328)$ & $(0.001)$ & $(0.683)$ & $(0.509)$ & (0.008) & (0.604) \\
\hline \multirow[t]{2}{*}{ BCLB } & & & & $0.609^{* * *}$ & -0.113 & 0.019 & $0.582^{* * *}$ & -0.138 & 0.078 \\
\hline & & & & $(0.000)$ & $(0.567)$ & $(0.949)$ & $(0.000)$ & $(0.520)$ & $(0.788)$ \\
\hline \multirow[t]{2}{*}{$\alpha_{0}$} & 2.242 & $33.536^{* * * *}$ & $22.826^{* * * *}$ & 1.045 & $13.358^{* * *}$ & $26.512^{* * *}$ & 1.530 & $13.912^{* * * *}$ & $24.321^{* * * *}$ \\
\hline & $(0.058)$ & $(0.000)$ & $(0.000)$ & (0.108) & $(0.000)$ & $(0.000)$ & $(0.058)$ & $(0.000)$ & $(0.000)$ \\
\hline \multirow[t]{2}{*}{$\varepsilon_{\mathrm{t}-1}^{2}$} & $0.169^{c}$ & 0.000 & $0.883^{\mathrm{a}}$ & $0.117^{* *}$ & $0.812^{* * * *}$ & $0.592^{* * * *}$ & $0.135^{* * *}$ & $0.738^{* * * *}$ & $0.639^{* * * *}$ \\
\hline & $(0.016)$ & (1.000) & $(0.000)$ & $(0.014)$ & $(0.000)$ & $(0.000)$ & $(0.020)$ & $(0.000)$ & $(0.000)$ \\
\hline \multirow[t]{2}{*}{$\mathrm{h}_{\mathrm{t}-1}$} & $0.698^{* * * *}$ & 0.000 & 0.000 & $0.794^{* * *}$ & 0.000 & 0.000 & $0.715^{* * *}$ & 0.000 & 0.000 \\
\hline & $(0.000)$ & (1.000) & (1.000) & $(0.000)$ & (1.000) & (1.000) & $(0.000)$ & (1.000) & (1.000) \\
\hline \multirow[t]{2}{*}{$\sqrt{h_{t}}$} & 0.172 & 0.000 & $-0.255^{*}$ & 0.227 & 0.094 & -0.099 & -0.486 & 0.142 & -0.178 \\
\hline & $(0.547)$ & $(1.000)$ & $(0.005)$ & $(0.480)$ & $(0.694)$ & $(0.624)$ & $(0.178)$ & $(0.583)$ & $(0.279)$ \\
\hline R-square & 0.32 & 0.32 & 0.30 & 0.55 & 0.47 & 0.45 & 0.61 & 0.47 & 0.46 \\
\hline LL & -733.05 & -838.26 & -886.79 & -685.73 & -787.81 & -872.48 & -671.56 & -787.82 & -866.33 \\
\hline AIC & 1478.10 & 1684.53 & 783.59 & 1391.46 & 1595.63 & 1762.96 & 1365.12 & 1595.63 & 1752.67 \\
\hline
\end{tabular}

Note: The dependent variables are the excess return of NAREIT index in column (1), winner portfolio in column (2), and loser portfolio in column (3). $* * *, * *$ and $*$ indicate the significant at $99.9 \%$ confidence level, significant at $99 \%$ confidence level, significant at $95 \%$ confidence level, respectively. 
Table 6: Wald test of OLS and GARCH-M models

Panel A: Cross sectional Analysis by Wald test

\begin{tabular}{|c|c|c|c|c|c|c|c|c|c|c|c|c|}
\hline & \multirow{2}{*}{$\begin{array}{l}\text { Model 1 } \\
\text { RMRF }\end{array}$} & \multicolumn{5}{|c|}{ Model 2} & \multicolumn{6}{|c|}{ Model 3} \\
\hline & & $\mathbf{S \& P}$ & RUSL & CAP & CSP & BCLB & RMRF & S\&P & RUSL & CAP & CSP & BCLB \\
\hline Wald $_{1}$ & $\begin{array}{l}29.980^{* * * *} \\
(0.000)\end{array}$ & $\begin{array}{l}19.723^{* * * *} \\
(0.000)\end{array}$ & $\begin{array}{l}8.649^{* *} \\
(0.034)\end{array}$ & $\begin{array}{l}16.079^{* * * *} \\
(0.001)\end{array}$ & $\begin{array}{l}4.200 \\
(0.241)\end{array}$ & $\begin{array}{l}5.056 \\
(0.168)\end{array}$ & $\begin{array}{l}13.641^{* * * *} \\
(0.003)\end{array}$ & $\begin{array}{l}20.903^{* * * *} \\
(0.000)\end{array}$ & $\begin{array}{l}6.350^{*} \\
(0.096)\end{array}$ & $\begin{array}{l}29.943^{* * * *} \\
(0.000)\end{array}$ & $\begin{array}{l}5.146 \\
(0.161)\end{array}$ & $\begin{array}{l}5.387 \\
(0.146)\end{array}$ \\
\hline Wald $_{2}$ & $\begin{array}{l}23.938^{* * * *} \\
(0.000)\end{array}$ & $\begin{array}{l}18.395^{* * *} \\
(0.000)\end{array}$ & $\begin{array}{l}8.647^{* * *} \\
(0.013)\end{array}$ & $\begin{array}{l}14.750^{* * * *} \\
(0.000)\end{array}$ & $\begin{array}{l}3.885 \\
(0.143) \\
\end{array}$ & $\begin{array}{l}3.580 \\
(0.167) \\
\end{array}$ & $\begin{array}{l}13.369^{* * * *} \\
(0.001)\end{array}$ & $\begin{array}{l}19.789^{* * * *} \\
(0.000)\end{array}$ & $\begin{array}{l}6.349^{* *} \\
(0.042)\end{array}$ & $\begin{array}{l}27.726^{* * * *} \\
(0.000)\end{array}$ & $\begin{array}{l}4.867^{*} \\
(0.088) \\
\end{array}$ & $\begin{array}{l}3.891 \\
(0.143) \\
\end{array}$ \\
\hline \multicolumn{13}{|c|}{ Panel B: Time series Analysis by Wald test } \\
\hline & Model 4 & & & Model 5 & & & & & Mod & & & \\
\hline & RMRF & S\&P & RUSL & CAP & CSP & BCLB & RMRF & S\&P & RUSL & CAP & CSP & BCLB \\
\hline Wald $_{1}$ & $\begin{array}{l}4.480 \\
(0.214)\end{array}$ & $\begin{array}{l}153.000^{* * * *} \\
(0.000)\end{array}$ & $\begin{array}{l}163.130^{* * *} \\
(0.000)\end{array}$ & $\begin{array}{l}81.270^{* * *} \\
(0.000)\end{array}$ & $\begin{array}{l}3.920 \\
(0.270)\end{array}$ & $\begin{array}{l}16.040^{* * *} \\
(0.001)\end{array}$ & $\begin{array}{l}6.680^{*} \\
(0.082)\end{array}$ & $\begin{array}{l}198.540^{* * * *} \\
(0.000)\end{array}$ & $\begin{array}{l}175.320^{* * *} \\
(0.000)\end{array}$ & $\begin{array}{l}97.340^{* * *} \\
(0.000\end{array}$ & $\begin{array}{l}3.560 \\
(0.313)\end{array}$ & $\begin{array}{l}0.050 \\
(0.998)\end{array}$ \\
\hline Wald $_{2}$ & $\begin{array}{l}4.000 \\
(0.136)\end{array}$ & $\begin{array}{l}130.200^{* * * *} \\
(0.000)\end{array}$ & $\begin{array}{l}137.530^{\text {**** }} \\
(0.000)\end{array}$ & $\begin{array}{l}77.060^{\text {**** }} \\
(0.000)\end{array}$ & $\begin{array}{l}2.410 \\
(0.299) \\
\end{array}$ & $\begin{array}{l}15.430^{* * *} \\
(0.000)\end{array}$ & $\begin{array}{l}1.140 \\
(0.565)\end{array}$ & $\begin{array}{l}186.370^{* * * *} \\
(0.000)\end{array}$ & $\begin{array}{l}171.570^{* * *} \\
(0.000)\end{array}$ & $\begin{array}{l}98.730^{* * *} \\
(0.000)\end{array}$ & $\begin{array}{l}0.650 \\
(0.732)\end{array}$ & $\begin{array}{l}0.040 \\
(0.979)\end{array}$ \\
\hline
\end{tabular}

Note: Wald $_{1}$ tests the null hypothesis that the NAREIT, winner and loser portfolio share the same strategy and sensitivity to the broad market signals as:

$\mathrm{H}_{0}: \beta_{i}^{\text {NAREIT,j }}=\beta_{i}^{\text {Winner, } j}=\beta_{i}^{\text {Loser, } j}$; Wald ${ }_{2}$ tests the null hypothesis that the winner and the loser portfolios share the same strategy and sensitivity to the broad market signals as

$\mathrm{H}_{0}: \beta_{i}^{\text {Winner }}=\beta_{i}^{\text {Loser }} . * * *, * *$ and $*$ indicate the significant at $99.9 \%$ confidence level, significant at $99 \%$ confidence level, significant at $95 \%$ confidence level, respectively. 


\section{CONCLUSION}

Our research and finding contribute to the existing literature by analysis the strategy of REITs in changes of the financial and physical real estate market movement. Then extended monthly data over 1989-2010 increase the reliability of explanation of relationships among Fama-French market portfolio, S\&P500 index, Russell2000 index, CRSP Cap-based Portfolio index, S\&P/Case-Shiller home price index as well as Barclay Capital long-term Government/Corporate bond index. Second, the conditional correlations and dynamic conditional correlations are examined to find the different magnitude of REITs sensitive to the change in NAREIT index, and REITs portfolios. These results support the time-varying characteristics of the REITs returns. Third, we have provided a simple method to assist us in understanding and measuring the time-varying feature of REITs market. The multi-factor return generating approaches are used to empirically investigate the cross-sectional sensitivity of REITs index and portfolios to large- and small-cap stock returns, bond returns and returns to unsecuritized real estate. The results show that REITs returns display the greatest sensitivity to both large- and small-cap stocks. However, there is no role for unsecuritized real estate in explaining REITs returns. We also found the GARCH-M model provide the better description of dynamic returns of NAREIT index, winner and loser portfolios. The Wald test results in Table 6 also suggest that winner and loser portfolios exhibit the different pattern of sensitivity to the market factors. The results of regressions indicate that REITs return exhibit the greater sensitivity to large- and small-cap stock index, and less closely with those of bond and real estate index. The results also suggest that REITs not be viewed as a complete substitute for investment in tangible property of real estate.

\section{AUTHOR INFORMATION}

Zhongyi Xiao is a Ph.D student in Department of Economics at Texas Tech University, USA. He has interested in various areas of financial economics, and focus on the performance of Real Estate Investment Trust market and the interactions between financial investment markets. E-mail: zhongyi.xiao@ttu.edu. Corresponding author.

Peng Zhao is an Associate Professor of Management information system in School of Economics and Business Administration, Chongqing University, China. He is teaching courses on information management and data procession at both undergraduate and graduate, and MBA level. His teaching methodology is application of all concepts presented to students that were developed from his professional experience and academic research.

Email: zhaopeng@cqu.edu.cn. Corresponding author.

Masha Rahnama is an Associate Professor in Department of Economics, Texas Tech University, USA. His research interests is focus on Macroeconomics and International Economics. Email: m.rahnamamoghadam@ttu.edu

Yaling Zhou is a Ph.D student in College of Economics and Management, Southwest University, China. She is interested in various areas of economics, i.e. Agricultural Economics and Public Finance.

\section{REFERENCES}

1. Barkham, R. \& Geltner, D. (1995). Price discovery in American and British Property Markets. Real Estate Economics, 23, 21-44.

2. Bollerslev, T. (1990). Modeling the Coherence in Short-Run Nominal Exchange Rates: A Multivariate Generalized Arch Model. The Review of Economics and Statistics, 72, 498-505.

3. Bollerslev, T. 1986. Generalized autoregressive conditional heteroskedasticity. Journal of Econometrics, 31, 307-327.

4. $\quad$ Bond, S.A. \& Patel, K. (2002). The Conditional Distribution of Real Estate Returns: Are Higher Moments Time Varying?. Journal of Real Estate Finance and Economics, 26,319-339.

5. Campbell, J. \& Hentschel, L. (1992). No news is good news: An asymmetric model of changing volatility in stock returns. Journal of Financial Economics, 31, 281-318.

6. Case, B., Yang, Y. \& Yildirim, Y. (2010). Dynamic Correlations among Asset Classes: REIT and Stock Returns. The Journal of Real Estate Finance and Economics, DOI: 10.1007/s11146-010-9239-2 
7. Chang, K.L., Chen, N.K., \& Charles K.(2011). Monetary Policy, Term Structure and Asset Return: Comparing REIT, Housing and Stock, Journal of Real Estate Finance and Economics, 43, 221-257.

8. Chiang, K.C. \& Kung, A.W. (2005). Bidding Dynamics in Multi-Unit Auctions: Empirical Evidence from Online Auctions of Certificates of Deposit. Journal of Financial Intermediation. 2, $239-252$.

9. Clayton, J. \& MacKinnon, G. (2000). Measuring and Explaining Changes in REIT Liquidity: Moving Beyond the Bid-Ask Spread, Real Estate Economics, 28, 89-115.

10. Clayton, J. \& Mackinnon, G. (2001). The Time-Varying Nature of the Link between REIT, Real Estate and Financial Asset Returns. Journal of Real Estate Portfolio Management, 7, 43-54.

11. Clayton, J. \& Mackinnon, G. (2003). The Relative Importance of Stock, Bond and Real Estate Factors in Explaining REIT Returns. Journal of Real Estate Finance and Economics, 27, 39-60.

12. Chui, A.W, Titman, S. \& Wei, K.C. (2003a). The Cross Section of Expected REIT Returns. Real Estate Economics, 31, 451-479.

13. Chui, A.W., Titman, S. \& Wei, K.C. (2003b). Intra-Industry Momentum: The Case of REITs. Journal of Financial Markets, 6, 363-387.

14. Engle R. F. (2002), Dynamic Conditional Correlation - A Simple Class of Multivariate GARCH model, Journal of Business and Economic Statistics, 20, 339-350.

15. Engle, R. F., Lilien, D. M. \& Robins, R.P. (1987). Estimating Time-varying Risk Premia in the Term Structure: The ARCH-M Model, Econometrica, 55, 391-408.

16. Engle, R.F. \&, Mustafa C. (1992). Implied ARCH models from options prices. Journal of Econometrics, 52, 289-311.

17. Fei P., Ding, L. \& Deng Y. (2010). Correlation and Volatility Dynamics in REIT Returns: Performance and Portfolio Considerations. The Journal of Portfolio Management, 36, 113-125.

18. Ghosh, C., Miles, M. \& Sirmans, C F. (1996). Are REITS stocks?. Real estate finance, 13, 46-53.

19. Giliberto, S. M. (1990). Equity Real Estate Investment Trusts and Real Estate Returns. Journal of Real Estate Research, 5, 259-264.

20. Glascock, J.L., Lu, C. \& Raymond, W.S. (2000). Further evidence on the integration of REIT, bond, and stock returns. Journal of Real Estate Finance and Economics, 20, 177-194.

21. Glascock, J.L., Lu, C. \& Raymond W.S. (2002). REIT Returns and Inflation: Perverse or Reverse Causality Effects?, Journal of Real Estate Finance And Economics, 24, 301-317.

22. Glosten, L., Jagannathan, R. \& Runkle, D. (1993). On the Relation between the Expected Value and the Volatility of Nominal Excess Return on Stocks. Journal of Finance, 48, 1779-1801.

23. Goodman, J. (2003). Homeownership and Investment in Real Estate Stocks. Journal of Real Estate Portfolio Management, 9, 93-105.

24. Henry, Ó.T. (2009). Regime switching in the relationship between equity returns and short-term interest rates in the UK, Journal of Banking \& Finance, 33,405-414.

25. Hung, S. \& Glascock, J.L. (2010). Volatilities and Momentum Returns in Real Estate Investment Trusts. The Journal of Real Estate Finance and Economics, 41,126-149.

26. Jegadeesh, N. \& Titman S. (1993). Returns to buying winner and selling loser: Implication for stock market efficiency, Journal of Finance, 48, 65-91.

27. Joseph, T. L., Wang, J., \& Webb, J.(2009). Idiosyncratic Risk and REIT Returns. The Journal of Real Estate Finance And Economics, 38, 420-442.

28. Khoo T., Hartzell D., \& Hoesli M. (1993). An Investigation of the Change in Real Estate Investment Trust Betas, Real Estate Economics, 21, 107-130.

29. Li Y.M. \& Wang, K. (1995). The predictability of REIT returns and market segmentation. The Journal of Real Estate Research, 10,471-482.

30. Liang, Y., McIntosh W. \& Webb J. (1995). Intertemporal Changes in the Riskiness of REITs. Journal of Real Estate Research, 10, 427-43.

31. Liang, Y. \& McIntosh, W. (1998). REIT style and performance. Journal of Real Estate Portfolio Management, 4(1):69-78.

32. Ling, D.C. \& Ryngaert, M.R. (1997). Valuation uncertainty, institutional involvement, and the underpricing of IPOs: The case of REITs, Journal of Financial Economics, 43,433-456. 
33. Liu, C.,H., Hartzell, D., Grissom,J., Terry V. \& Greig W. (1990). The Composition of the Market Portfolio and Real Estate Investment Performance. Real Estate Economics, 18, 49-75.

34. Liu, C.H. \& Mei, J. (1992). The predictability of returns on equity REITs and their co-movement with other assets. Journal of Real Estate Finance and Economics, 5, 401-418.

35. Meyer, F.C. \& Webb, J.R. (1994). Statistical properties of returns: financial assets versus commercial real estate. Journal of Real Estate Finance and Economics, 8, 267-282.

36. Nelling, E. \& Gyourko, J. (1998). The Predictability of Equity REIT Returns. Journal of Real Estate Research, 16, 251-268.

37. Nelson, D. (1990). Conditional heteroskedasticity in asset returns: A new approach. Econometrica, 59, 347-370.

38. Payne, J.E. (2003). Shocks to macroeconomic state variables and the risk premium of REITs. Applied Economic Letters, 10,671-677.

39. Sagalyn L. B. (1990) Real Estate Risk and the Business Cycle: Evidence from Security Markets. Journal of Real Estate Research, 5, 203-219.

40. Sander A.B. \& Karolyi G.A. (1998). The variation of Economic Risk Premium in Real Estate Returns. Journal of Real Estate Finance and Economics, 17, 245-262.

41. Stevenson, S. (2002). An Examination of Volatility Spillovers in REIT Returns. Journal of Real Estate Portfolio Management, 8,229-238.

42. Subrahmanyam A. (2007). Liquidity, Return and Order-Flow Linkages between REITs and the Stock Market. Real Estate Economics, 35, 383-408.

43. Swanson,Z., Theis, J. \& Casey K.M. (2005). REIT Risk Premium Sensitivity and Interest Rates, Journal of Real Estate Portfolio Management, 11, 55-80.

44. Viond, C. (1999). Time-Series Properties and Diversification Benefits of REIT Returns. Journal of Real Estate Research, 17, 91-112.

45. Wu P. \& Huang C. (2011). Effects of Structural changes on the risk characteristics of REIT returns. International Review of Economics \& Finance, 20, 645-653. 